\title{
Larva monitoring on elementary school students (SD) as prevention of dengue fever (DBD)
}

\author{
Sri Novita Lubis ${ }^{1 *}$, Puteri CCA ${ }^{1}$, Lanova Dwi A ${ }^{1}$, Umi Salmah ${ }^{1}$ \\ ${ }^{1}$ Faculty of Public Health, Universitas Sumatera Utara, Medan, Indonesia \\ *Email: srinovita@usu.ac.id
}

\begin{abstract}
Dengue hemorrhagic fever (DHF) in North Sumatra is a health problem that always occurs throughout the year. Based on the 2017 DHF report, Medan City is one of the regencies / cities that is included as a DHF endemic in North Sumatra. Karya Bakti Private Elementary School is one of the schools in the city of Medan. To solve this problem, community service activities are carried out in the form of training to increase students' knowledge about the prevention of DHF as well as the formation of larvae monitors. As for the number of training participants as many as 62 people coming from grade 5 students. School-age children are expected to be agents of change for the environment around their homes so that the incidence of DHF can be minimized. There is a difference in knowledge before and after training. While attitudes towards the prevention of DHF statistically showed no difference in knowledge before and after training.
\end{abstract}

Keyword: DBD, Elementary School, larva

\begin{abstract}
Abstrak
Demam berdarah dengue (DBD) di Sumatera Utara merupakan masalah kesehatan yang selalu terjadi sepanjang tahun. Berdasarkan laporan DBD tahun 2017, Kota Medan merupakan salah satu kabupaten/kota yang termasuk endemis DBD di Sumatera Utara. SD Swasta Karya Bakti termasuk salah satu sekolah yang berada di Kota Medan. Untuk menyelesaikan permasalahan tersebut, dilakukan kegiatan pengabdian kepada masyarakat berupa pelatihan untuk meningkatkan pengetahuan siswa-siswi tentang pencegahan DBD sekaligus dilakukan pembentukan juru pemantau jentik. Adapun jumlah peserta pelatihan sebanyak 62 orang yang berasal dari siswa- siswi kelas 5. Anak usia sekolah ini diharapkan dapat menjadi agen perubahan bagi lingkungan sekitar tempat tinggalnya sehingga kejadian DBD dapat diminimalkan. Ada perbedaan pengetahuan sebelum dan sesudah pelatihan. Sedangkan sikap terhadap pencegahan DBD menunjukkan secara statistik tidak ada perbedaan pengetahuan sebelum dan sesudah pelatihan.
\end{abstract}

Kata Kunci : DBD, SD, jentik

\section{PENDAHULUAN}

Demam berdarah dengue (DBD) di Sumatera Utara merupakan masalah kesehatan yang selalu terjadi sepanjang tahun. Penyebaran DBD semakin lama semakin meluas. Berdasarkan laporan DBD tahun 2017, terdapat 31 kabupaten/kota yang termasuk endemis DBD di Sumatera Utara. Vektor DBD adalah nyamuk Aedes aegypti dan Aedes albopictus yang berada di sekitar rumah dan pemukiman masyarakat. Kelompok masyarakat yang paling rentan terkena DBD adalah anak usia $<15$ tahun (usia sekolah). Laporan DBD tahun 2017, sebanyak 52,5\% (2.863 orang) kasus DBD terjadi pada kelompok usia tersebut. Anak usia sekolah tersebut berada di sekolah sejak pagi hingga siang atau sore hari. Nyamuk vektor DBD aktif menghisap darah pada pagi (sekitar pukul 8-10) dan sore hari (sekitar pukul 15-17). Sehingga kemungkinan anak usia sekolah tersebut tertular itu, pencegahan DBD selain difokuskan di rumah sebaiknya juga dilakukan di sekolah (Dinkes Provsu, 2018). 
DBD dapat dihindari bila Sistem Kewaspadaan Dini (SKD) dan pengendalian vektor dilakukan dengan baik, terpadu dan berkesinambungan. Pengendalian vektor melalui surveilans vektor diatur dalam Kepmenkes No.581 tahun 1992, bahwa kegiatan pemberantasan sarang nyamuk (PSN) dilakukan secara periodik oleh masyarakat yang dikoordinir oleh RT/RW dalam bentuk PSN dengan pesan inti 3M plus. Keberhasilan kegiatan PSN antara lain dapat diukur dengan Angka Bebas Jentik (ABJ). Apabila ABJ lebih atau sama dengan 95\% diharapkan penularan DBD dapat dicegah atau dikurangi (Kemenkes RI, 2010).

Peran serta masyarakat merupakan komponen utama dalam pengendalian DBD, sebab vektor DBD nyamuk Aedes jentiknya ada di sekitar pemukiman dan tempat istirahat nyamuk dewasa sebagian besar ada di dalam rumah. Hingga saat ini peran serta masyarakat dalam pelaksanaan pemberantasan sarang nyamuk (PSN) belum optimal, masih banyak masyarakat yang belum melakukan PSN secara rutin. Peran serta masyarakat dalam hal ini adalah peran serta sebagai kader juru pemantau jentik (Jumantik) yang melaksanakan pemantauan jentik. PSN yang dilakukan secara rutin seminggu sekali, meliputi kegiatan menguras, menutup dan mengubur atau memanfaatkan kembali barangbarang yang bernilai ekonomis (3M). PSN 3M secara rutin dapat membantu menurunkan kepadatan vektor, berdampak pada menurunnya kontak antara manusia dengan vektor, akhirnya terjadinya penurunan kasus DBD (Jafar, N, dkk, 2019).

Kota Medan merupakan salah satu daerah endemis Demam Berdarah Dengue (DBD) di Provinsi Sumatera Utara. Berbagai upaya yang telah dilakukan Dinas Kesehatan Kota Medan dalam upaya menurunkan angka kejadian (insidens) DBD, misalnya berkoordinasi dengan Puskesmas melakukan sosialisasi bersama kepala sekolah, para ibu pengajian dan seluruh kepala lingkungan untuk memotivasi masyarakat aktif setiap minggunya melakukan Pemberantasan Sarang Nyamuk (PSN). Namun demikian, masih sebagian kecil masyarakat mau berpartisipasi dalam kegiatan PSN. Ada beberapa kegiatan yang sudah dilaksanakan oleh pihak kecamatan terkait PSN seperti penyuluhan pada masyarakat, ke sekolah, tempat ibadah, melakukan fogging dalam membatasi meningkatnya angka jangkitan dan melakukan kegiatan gotong royong setiap hari Jum'at.

Salah satu kegiatan PSN yang dilakukan adalah melakukan Pemeriksaan Jentik Berkala (PBJ) oleh juru pemantau jentik (Jumantik). Kegiatan PSN ini diperkuat dengan dikeluarkannya surat pemberitahuan dari Walikota Medan ke setiap kecamatan yang ada di Medan untuk mengkoordinir kegiatan PSN sebagai kegiatan rutin setiap minggu di wilayah masing-masing. Cara memutus rantai penularan DBD adalah dengan melakukan PSN secara serentak dan teratur, baik di rumah, di sekolah dan di tempat umum lainnya.

Meskipun sudah ada upaya yang dilakukan oleh pemerintah daerah Kota Medan dalam pencegahan dan penanggulangan DBD namun dalam kenyataannya Kota Medan masih menjadi daerah endemis DBD. Hal ini disebabkan oleh masih rendahnya peran serta dari seluruh lapisan masyarakat dalam kegiatan PSN dan pemantauan jentik secara berkala (PJB). Oleh karena itu, perlu dilakukan peningkatan peran serta seluruh lapisan masyarakat yang ada di Kota Medan melalui kegiatan Pengabdian Pada Masyarakat (PPM) untuk mengaktifkan kegiatan pencegahan DBD mulai dari unit terkecil di masyarakat yaitu rumah tangga.

Sumber daya yang dapat dilibatkan dalam kegiatan ini adalah anak sekolah dasar. Melalui sumber daya inilah diharapakan anak sekolah dapat ikut mendukung program pemerintah dalam upaya pencegahan DBD sehingga kegiatan ini dapat dilaksanakan secara terus-menerus di masyarakat sehingga insidens kasus DBD akan menurun.

\section{METODE PELAKSANAAN}

Kegiatan pengabdian masyarakat ini dilakukan dengan merekrut siswa-siswi kelas 5 sekolah dasar (SD) sebagai juru pemantau jentik, pelatihan jumantik PSN pada anak sekolah, pelaksanaan pemantauan jentik di lingkungan rumah jumantik, dan monitoring dan evaluasi pelaksanaan 
pemantauan jentik di lingkungan rumah jumantik. Kegiatan pelatihan jumantik dilaksanakan pada hari Jum'at tanggal 26 bulan Juli tahun 2019. Kegiatan ini bertujuan untuk meningkatkan pengetahuan jumantik dalam hal pencegahan dan penanggulangan penyakit DBD. Adapun sekolah dasar yang terpilih adalah SD Swasta Karya Bakti Medan yang beralamat di Jalan Karya Ujung Kecamatan Medan Barat Kota Medan.

Kegiatan pengabdian masyarakat ini diawali dengan sosialisasi kepada pihak sekolah, persiapan pelatihan, kegiatan pelatihan jumantik, pelaksanaan pemantauan jentik di lingkungan rumah jumantik, dan monitoring dan evaluasi pelaksanaan pemantauan jentik di lingkungan rumah jumantik. Pada saat kegiatan pelatihan diawali dengan pre test peserta. Tujuan pre test ini untuk mengetahui tingkat pengetahuan peserta tentang pencegahan DBD sebelum dilaksanakan pelatihan. Pelatihan disampaikan dengan pemutaran video tentang DBD dan dilanjutkan dengan pemberian materi dengan metode ceramah menggunakan media power point. Setelah pemberian materi masuk ke sesi tanya jawab dan kegiatan post test. Kemudian dilakukan pemberian alat bantu pemeriksaan jentik secara simbolis kepada perwakilan jumantik.

Tim pengabdian memberikan penjelasan kepada jumantik tentang tugas mereka untuk melakukan pemantauan jentik di lingkungan rumah dan melakukan pengisian lembar observasi pemantauan jentik atas hasil pemeriksaan tersebut.

Lembar observasi ini akan diambil oleh tim pengabdian sebagai evaluasi atas pelaksanaan kegiatan pemantauan jentik tersebut.

\section{HASIL DAN PEMBAHASAN}

Dari kegiatan pengabdian masyarakat ini telah terbentuk 62 orang juru pemantau jentik yang berasal dari siswa-siswi kelas 5 SD Swasta Karya Bakti Medan. Hasil kegiatan pre test dan post test disajikan pada tabel 3.1 dan tabel 3.2.

Tabel 3.1. Pengetahuan sebelum dan sesudah pelatihan

\begin{tabular}{cccc}
\hline & Mean & LK 95\% & Nilai p \\
\hline Pre-test & 5,47 & $-1,800--$ & 0,000 \\
Post-test & 6,7 & 0,845 & \\
\hline
\end{tabular}

Berdasarkan tabel 3.1 di atas didapatkan bahwa nilai rata-rata pengetahuan sebelum kegiatan pelatihan (pre test) sebesar 5,47 dan hasil post test sebesar 6,79. Dari hasil uji statistik menggunakan Paired Samples Test untuk pengetahuan pencegahan DBD sebelum dan sesudah diberi pelatihan tentang pencegahan dan pennggulangan DBD. Hasil uji menunjukkan nilai $\mathrm{p}<$ 0,05 artinya ada perbedaan pengetahuan pencegahan DBD sebelum dan sesudah diberi pelatihan

Tabel 3.2. Sikap sebelum dan sesudah pelatihan

\begin{tabular}{cccc}
\hline & Mean & LK 95\% & Nilai p \\
\hline Pre-test & 22,56 & $-1,087$ & $-0,507$ \\
Post-test & 22,85 & & 0,469 \\
\hline
\end{tabular}

Berdasarkan tabel 3.2 di atas dapat diketahui bahwa nilai rata-rata sikap peserta terhadap pencegahan pada saat pre test sebesar 22,56 dan hasil post test sebesar 22,85. Dari hasil uji statistik menggunakan Paired Samples Test untuk sikap terhadap pencegahan DBD sebelum dan sesudah diberi pelatihan tentang pencegahan dan pennggulangan DBD. Hasil uji menunjukkan nilai $p>$ 0,05 artinya tidak ada perbedaan sikap terhadap pencegahan DBD sebelum dan sesudah diberi pelatihan. 
Hasil lain dari pelaksanaan kegiatan pengabdian masyarakat ini adalah terdistribusinya alat bantu untuk melakukan pemeriksaan jentik berupa lampu senter dan SD Swasta Karya Bakti mendapatkan bantuan tempat sampah untuk di ruang kelas.

Metode pengendalian vektor dan mengurangi kontak antara vektor-manusia merupakan cara yang paling efektif untuk mencegah timbulnya demam berdarah dengue berserta implikasinya (Renganathan, E., et.al, 2003). Pada Peraturan Menteri Kesehatan RI No 50 Tahun 2017 pasal 14 telah disebutkan bahwa pengendalian vektor dan binatang pembawa penyakit, dapat mendayagunakan kader kesehatan terlatih atau penghuni/anggota keluarga untuk lingkungan rumah tangga. Hal ini merupakan suatu konsep pengendalian dengan pemberdayaan dan hal ini didukung dengan bantuan tenaga kesehatan. Ginanjar (2009) mengemukakan bahwa nyamuk aedes aegypti menyukai tinggal di genangan air yang bersih dan tidak bersentuhan langsung dengan tanah. Jika nyamuk aedes aegypti sudah tinggal digenangan air yang bersih maka telurnya akan berkembangbiak di genangan tersebut. Beberapa tempat genangan air bersih yang disukai oleh vektor DBD dapat berupa kaleng bekas, tempat penampungan air yang terbuka, bak mandi, ban bekas, dan lain sebagainya. Dalam kegiatan pengabdian masyarakat ini juru pemantau jentik diberi pengetahuan untuk mengetahui dimana saja tempat perkembangbiakan nyamuk aedes aegypti yang ada di sekitar mereka.

Pemberdayaan masyarakat dalam bidang kesehatan dapat dilaksanakan dengan model partisipasi komunitas. Dalam upaya pengendalian DBD partisipasi masyarakat sangat penting. Upaya pengendalian DBD dilakukan dengan pengendalian dan pengelolaan terpadu untuk pencegahan DBD dan manajemen vektor terpadu. Hal ini menggabungkan mobilisasi sosial dan perubahan perilaku masyarakat. Masyarakat diajak untuk melakukan perubahan perilaku yang baik melalui berbagai macam cara seperti kampanye, penyuluhan, dan pelatihan tentang pengendalian vektor DBD. Hal ini bertujuan selain untuk mengendalikan DBD juga meningkatkan efikasi, efektivitas biaya, dampak lingkungan yang minimal dan keberlanjutan program pengendalian DBD (Roberto. Tapia-conyer, et.al, 2012; Breilh J., et.al, 2015).

Sekolah merupakan salah satu tempat yang berisiko untuk terjadinya penularan maupun perkembangbiakan nyamuk aedes aegypti. Di sekolah juga dapat dilakukan pemberdayaan kepada siswa-siswi sekolah untuk melakukan pencegahan terhadap penyakit DBD. Anak sekolah dibekali dengan pengetahuan tentang pencegahan DBD, pentingnya menjaga kebersihan lingkungan dan keterampilan untuk melakukan pemeriksaan jentik baik di lingkungan sekolah maupun di lingkungan sekitar tempat tinggalnya. Anak usia sekolah merupakan usia yang tepat untuk memberikan pengetahuan pencegahan DBD dan diharapkan pada usia tersebut dapat menjadi agent of change.

Lingkungan yang bersih akan mampu menekan laju pertumbuhan dan perkembangan nyamuk aedes aegypti sebagai vektor penyebab penyakit DBD ((Rahayu \& Ustiawan, 2013; Fadilla dkk., 2015).

Sebagai awal dari tahap implementasi kegiatan pengabdian masyarakat ini berupa pelatihan Juru Pemantau Jentik, Pemberantasan Sarang Nyamuk DBD. Kegiatan ini bertujuan untuk memberikan pelatihan kepada juru pemantau jentik yang telah dibentuk sebagai upaya awal dalam mencegah pertumbuhan dan perkembangbiakan jentik nyamuk yang menjadi penyebab DBD.

Berdasarkan hasil pre test dan post test dalam program pengabdian masyarakat ini diperoleh peningkatan pengetahuan dari peserta jumantik. Terdapat peningkatan nilai rata rata pengetahuan. Dari hasil uji statistik menggunakan Paired Samples Test untuk pengetahuan pencegahan DBD sebelum dan sesudah diberi pelatihan tentang pencegahan dan pennggulangan DBD. Hasil uji menunjukkan nilai $\mathrm{p}<0,05$ artinya ada perbedaan pengetahuan pencegahan DBD sebelum dan sesudah diberi pelatihan. Dengan peningkatan pengetahuan ini diharapkan kesadaran untuk memberantas nyamuk dan mencegah kejadian DBD juga meningkat. Namun berdasarkan sikap dari hasil uji statistik menunjukkan nilai $\mathrm{p}>0,005$ artinya tidak ada perbedaan sikap pencegahan DBD sebelum dan sesudah diberi pelatihan. 
Setiap kader jumantik yang telah dibentuk memiliki kewajiban untuk melakukan pemeriksaan jentik di lingkungan sekitar tempat tinggalnya dengan menggunakan form lembar observasi pemeriksaan jentik yang telah didistribusikan pada saat pelatihan. Kemudian form isian tersebut dikumpulkan kepada koordinator jumantik untuk kemudian diserahkan kepada tim pengabdian sebagai evaluasi dari pelaksanaan kegiatan pemantauan jentik tersebut.

\section{KESIMPULAN}

Kegiatan pengabdian kepada masyarakat berupa pembentukan juru pemantau jentik (jumantik) merupakan hal yang sangat penting dilakukan untuk memutus penyebaran penyakit DBD dan melakukan upaya pencegahan penyakit DBD. Dampak positif dari kegiatan pengabdian ini adalah adanya kegiatan pemantauan jentik secara berkala yang akan rutin dilakukan oleh kader jumantik sehingga angka kejadian DBD dapat diturunkan.

\section{UCAPAN TERIMAKASIH}

Terima kasih tim pengabdian ucapkan kepada Lembaga Pengabdian Masyarakat (LPPM) USU Tahun 2019, SD Swasta Karya Bakti Medan dan seluruh pihak yang telah ikut membantu pelaksanaan kegiatan pengabdian masyarakat ini.

\section{DAFTAR PUSTAKA}

Breilh J, Spiegel J, Wilches AA, Mitchell- foster K, Delgado JA. Integrating participatory community mobilization processes to improve dengue prevention : an eco-bio-social scaling up of local success in. Journal Transactions of The Royal Society of Tropical medicine and $\mathrm{H}$ y g i e ne. 1092015 .: 126 - 133 .doi:10.1093/trstmh/tru209

Dinkes Provsu. (2018). Pembentukan Kader Barisan Cilik Pemberantas Jentik (Balik Petik) di Kota Medan. Retrieved from http://dinkes.sumutprov.go.id/v2/berita- 348-pembentukankader-barisan-cilik- pemberantas-jentik-balik-petik-di-kota- medan.html

Fadilla, Z., Hadi, U. K., \& Setiyaningsih, S., (2015). Bioekologi vektor demam berdarah dengue (DBD) serta deteksi virus dengue pada Aedes aegypti (Linnaeus) dan Ae. albopictus (Skuse) (Diptera: Culicidae) di kelurahan endemic DBD Bantarjati, Kota Bogor, Jurnal Entomologi Indonesia, 12(1): 31-38.

Jafar, N., Fadilah N., Malasari, S., Setyawati, A., Syafar, M., Wahyuni, A. (2019). Mosquito Nests Eradication Through Monitoring The Mosquito Larva (Jumantik) By School Children In Preventing Dengue Hemorrhagic Fever. Indonesian Contemporary Nursing Journal, 3(2), 8 14. Retrieved from http://journal.unhas.ac.id/index.php/ic on/article/view/3667

Kementerian kesehatan Republik Indonesia. Standar Baku Mutu Kesehatan Lingkungan dan Persyaratan Kesehatan untuk Vektor dan Binatang Pembawa Penyakit serta Pengendalia nnya . Peraturan Menteri Kesehatan Republik Indonesia. 2017; Nomor 50

Kemenkes R.I., (2010). Demam Berdarah Dengue. Buletin Jendela Epidemiologi. Volume 2, Agustus 2010.

Rahayu, D. F. \& Ustiawan, A, (2013). Identifikasi Aedes aegypti dan Aedes albopictus, Balaba, 9(01): 7-10 
Renganathan E, et al,. Towards Sustaining Behavioural Impact in Dengue Prevention and Control. Dengue Bulletin. 2003;27

Roberto. Tapia-conyer, Méndez-galván J, Burciagazúñiga P, et al. Paediatrics and International Child Health Community participation in the prevention and control of dengue : the patio limpio strategy in Mexico Community participation in the prevention and control of dengue : the patio limpio strategy in Mexico. $2013 ; .32(\mathrm{~S} 1): 10-13$ doi:10.1179/2046904712Z.00000000047.Retrieved from https://www.ncbi.nlm.nih.gov/pmc/art icles/PMC3381439/ 